\title{
Karakteristik Kimia dan Evaluasi Sensori Produk Ikan Teri Kering Lokal di Desa Toniku
}

\author{
Ruslan A. Daeng ${ }^{\varpi^{\varpi}}$ dan IbnuW. Laitupa ${ }^{1}$ \\ ${ }^{1}$ Staf Pengajar Prodi THP Fakultas Pertanian, Universitas Muhammadiyah Maluku Utara. Ternate. Indonesia, \\ Email : ruslan daeng@yahoo.com, ibnulaitupa3@gmail.com \\ Korespondensi : Ruslan A. Daeng, Universitas Muhammadiyah Maluku Utara, Ternate, Indonesia, \\ Email : ruslan_daeng@yahoo.com
}

\begin{abstract}
ABSTRAK
Penelitian ini dilaksanakan di Laboratorium Pengolahan Hasil Perikanan THP UMMU Ternate untuk uji organoleptik dan Laboratorium Ilmu Pangan IPB untuk uji Kimia, dengan tujuan untuk mengetahui mutu organoleptik dan kimia pada produk lokal ikan teri kering yang diproduksi oleh masyarakat di Desa Toniku Kabupaten Halmahera Barat Provinsi Maluku Utara. Penggunaan analisa mutu ditinjau dari aspek organoleptik dan kimia serta rancangan percobaan yang digunakan dalam penilitian ini adalah Rancangan Acak Lengkap (RAL) faktor tunggal serta analisis varian (Anova)dan hasil uji organoleptik dihitung menggunakan nilai rata-rata dan standar Deviasi dalam metode penelitian diharapkan menjawab tujuan penelitian. Hasil penelitisan didapat bahwa hasil pengujian organoleptik ikan teri kering yang dihasilkan oleh nelayan/pengusaha ikan di Desa Toniku masih sesuai dengan standar mutu organoleptik yang ditetapkan, dengan rata-rata nilai dari ke empat parameter adalah Kenampakan (8-7), Bau (8-7), Rasa (7), Konsistensi (8-7). Hasil Uji karakteristik kimiawi meliputi kadar air dengan nilai $(2,08$ pada penyimpanan 3 bulan, sedangkan nilai terendah adalah 1,27), kadar abu (1,83 yaitu diperoleh pada penyimpanan 3 bulan. Sedangkan nilai terendah adalah 1,01 yaitu diperoleh pada penyimpanan bulan), kadar protein (7,38 yaitu diperoleh pada penyimpanan 3 bulan. Sedangkan nilai terendah 7,36 yaitu diperoleh pada penyimpanan 1 bulan dan 2 bulan), kadar lemak (22,94 yaitu diperoleh pada penyimpanan 3 bulan. Sedangkan nilai terendah adalah 20,08 yaitu diperoleh pada penyimpanan 1 bulan) dan Karbohidrat (1,48 yaitu diperoleh pada penyimpanan 3 bulan. Sedangkan nilai terendah adalah 1,22 yaitu diperoleh pada penyimpanan 1 bulan)
\end{abstract}

\section{Keyword: Organoleptik, kimia, ikan teri kering}

\section{PENDAHULUAN}

\subsection{Latar Belakang}

Provinsi Maluku Utara merupakan provinsi kepulauan yang terletak sangat strategis karena berada pada bibir pasifik (pacific ring) dan menjadi lintasan dua benua yaitu benua Asia dan benua Australia, dengan beriklim tropis memungkinkan sektor perikanan dan kelautan sangat melimpah dan beraneka ragam. Salah satu potensi lestari Provinsi Maluku Utara yang perlu dikembangkan adalah jenis ikan pelagis kecil seperti ikan teri (Stelophorus heterelubus).

Potensi sumberdaya ikan (standing stock) yang terdapat di perairan Maluku Utara diperkirakan mencapai 694.382,48 ton dengan jumlah potensi lestari yang dapat dimanfaatkan (Maximum Sustainable Yield, MSY) sebesar 347.191,24 ton/tahun, yang terdiri dari ikan pelagis besar sebesar 211.590,00 ton/tahun dan ikan demersal 135.005,24 ton/tahun dari potensi tersebut menunjukkan bahwa sumberdaya perairan Maluku Utara cukup prospektif untuk dikelola dan dimanfaatkan secara berkelanjutan (Alwi, 2014).

Secara administrasi Kabupaten Halmahera Barat terletak di wilayah Propinsi Maluku Utara. Luas wilayah Kabupaten Halmahera Barat sekitar 14.253,66 km2, yang terdiri dari luas lautan $11.253,50 \mathrm{~km} 2$ dan luas daratan 3.108,16 km2. Produksi perikanan laut Kabupaten Halmahera Barat pada tahun 2006 sebesar 76.261,41 ton terdiri dari jenis pelagis besar 46.124,34 ton, pelagis kecil 18.909,86 ton dan demersal sekitar 11.227,21 ton (Dinas Kelautan Perikanan Halmahera Barat, 2016). Salah satu wilayah di Kabupaten Halmahera Barat yang memiliki potensi dan sumberdaya ikan pelagis 
kecil adalah Teluk Dodinga, dimana kegiatan perikanan tangkap berkembang dengan baik serta menjadi salah satu sentra produksi ikan teri kering yang ada di Maluku Utara.

Ikan teri banyak diolah karena mempunyai arti penting sebagai bahan makanan yang dapat dimanfaatkan baik sebagai ikan segar maupun ikan kering. Sumberdaya ikan teri yang melimpah di Indonesia merupakan suatu peluang untuk mengembangkan usaha ikan teri asin kering yang telah banyak dikerjakan oleh industri pengolahan tradisional. Proses pengeringan ikan teri asin akan semakin menambah penurunan kadar air dalam tubuh ikan, sekaligus menjadi faktor penghambat pertumbuhan mikroba.

Umumnya nelayan atau pengusaha ikan di Desa Toniku Kabupaten Halmahera Barat dan Provinsi Maluku Utara pada umumnya melakukan pengeringan ikan masih secara tradisional yaitu dengan memanfaatkan tenaga surya secara langsung. Hal ini dilakukan karena pengeringan ikan dengan memanfaatkan tenaga surya merupakan cara pengeringan warisan turun temurun dan mempunyai beberapa keuntungan, yaitu: sederhana, biaya rendah dan tidak memerlukan banyak tenaga kerja. Pengeringan cara ini biasanya dilakukan dengan meletakan produk di atas jaring ikan, tikar, hamparan lantai semen atau anyaman bambu dan ditempatkan di bawah sinar matahari. Metode ini tidak hygienis dan memungkinkan produk yang dikeringkan kehilangan sebagian beratnya, karena dimakan serangga, burung, kucing atau hewan lainnya. Selain itu juga, produk akan dengan mudah terkena debu dan proses pengeringan akan tertunda jika hujan, sehingga hasil yang diperoleh tidak maksimal, serta jumlah produksi yang dihasilkan tidak sesuai harapan.

Melihat permasalahan-permasalahan yang terjadi pada produk lokal unggulan ikan teri kering yang dihasilkan oleh masyarakat di Desa Toniku dan Maluku Utara umumnya, maka penelitian ini lebih diarahkan pada analisis mutu organoleptik dan kimia untuk mengetahui tingkat kesukaan konsumen dan nilai gizi.

Tujuan dari penelitian ini adalah untuk mengetahui mutu organoleptik dan kimia pada produk lokal ikan teri kering yang diproduksi oleh masyarakat di Desa Toniku Kabupaten Halmahera Barat Provinsi Maluku Utara.Adapun manfaat dari penelitian ini adalah untuk menambah informasi ilmiah bagi masyarakat pengolah ikan teri kering dan Provinsi Maluku Utara pada umumnya, tentang tingkat kesukaan konsumen dan informasi nilai gizi. Selain itu, hasil penelitian ini diharapkan bisa bermanfaat bagi pemerintah atau pihak yang berwewenang untuk melaksanankan pengembangan dan pembinaan mutu hasil

\section{METODE PENELITIAN}

\subsection{Tempat dan Waktu Penelitian}

Penelitian ini dimulai sejak bulan Mei sampai Agustus 2019, untuk pengambilan sampel di Desa Toniku Kabupaten Halmahera Barat dan di Laboratorium Ilmu Pangan IPB untuk analisis kimia.

\subsection{Alat dan Bahan}

Alat-alat yang digunakan untuk uji kimia adalah cawan porselin, desikator, labu Kjeldahl, alat ekstraksi Soxhlet, kertas saring Whatman No.42, erlemeyer, spektrofotometer, kuvet, pipet, kapas wool bebas lemak, tabung reaksi, gelas ukur dan alat-alat untuk uji organoleptik menggunakan lembaran scoresheet.

Adapun bahan baku yang digunakan dalam penelitian ini adalah ikan teri kering yang diperoleh di Desa Toniku Kabupaten Halmahera Barat. Bahan-bahan kimia yang digunakan untuk uji kimia aguades, $\mathrm{NaOH}, \mathrm{HCl}, \mathrm{H}_{3} \mathrm{BO}_{3}, \mathrm{H}_{2} \mathrm{SO}_{4}, \mathrm{H}_{2} \mathrm{O}$, tablet Kjeltab, larutan hexana, buffer asam dan basa.

\subsection{Prosedur Analisis Laboratorium}

\subsubsection{Uji Organoleptik}

\subsubsection{Uji Kimia}
a. Kadar air (AOAC, 1995)
b. Kadar abu (AOAC, 1995)
c. Kadar protein (AOAC, 1995)
d. Kadar lemak (AOAC, 1995)
e. Karbohidratby difference (AOAC, 1995) 


\subsection{Rancangan Percobaan}

Rancangan percobaan yang digunakan dalam penilitian ini adalah Rancangan Acak Lengkap (RAL) faktor tunggal, yaitu lama penyimpanan dengan 3 taraf yaitu $A_{1}=1$ bulan, $A_{2}=2$ bulan, dan $A_{3}=$ 3 bulan. Masing - masing perlakuan diulang sebanyak 3 kali. Model Rancangan : $Y_{i j}=\mu+A_{i}+\varepsilon_{i j}$ (Steel dan Torrie, 1991).

Dimana :

$\mathrm{Y}_{\mathrm{ij}}=$ Respon percobaan karena pengaruh perlakuan faktor A taraf ke-i, pada ulangan ke-j.

$\mu=\quad$ Nilai tengah umum atau rata-rata

$A_{i}=$ Pengaruh lama penyimpananikan teri kering faktor A ke-i $(1,2,3$,

$\varepsilon_{\mathrm{ijk}}=$ Galat percobaan

Data hasil pengujian secara organoleptik dan kimia dianalisis menggunakan analisis varian (Anova). Jika data hasil pengujian berpengaruh nyata, maka akan dilanjutkan dengan uji Beda Nyata Terkecil (BNT). Adapun rumus matematik yang digunakan adalah sebagai berikut (Steel dan Torrie, 1991).

$\mathrm{BNT}=\mathrm{t} \alpha ; \operatorname{dbg} \mathrm{x} \sqrt{\frac{2 .(K T G)}{r}}$

Ket :

t $\alpha=$ nilai $\mathrm{t}$ pada alfa 0,05 atau $0,01 \%$

$\mathrm{dbg}=$ derajat bebas galat

KTG = kuadrat tengah galat

$\mathrm{r} \quad=$ ulangan

\section{HASIL DAN PEMBAHASAN}

4.1.Karakteristik Mutu Organoleptik Ikan Teri Kering

\section{Kenampakan}

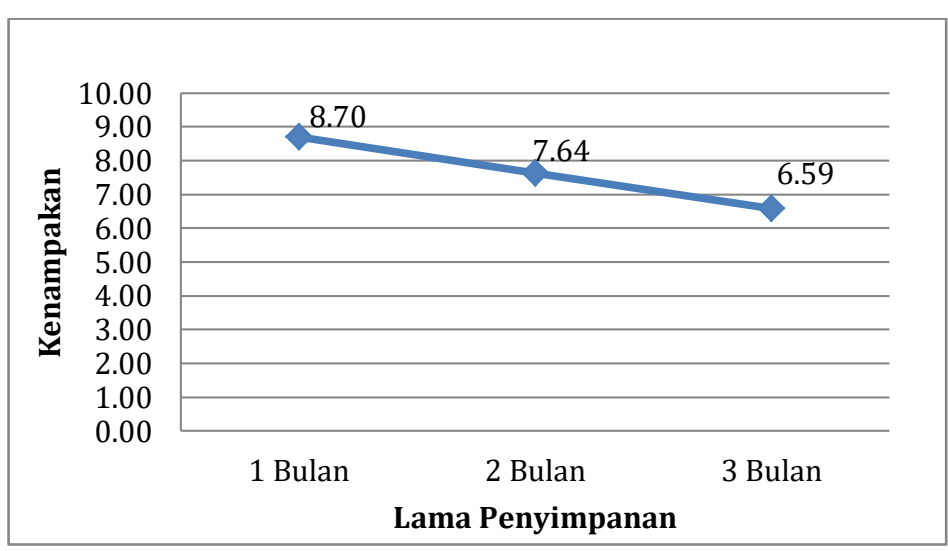

Gambar 1. Grafik Nilai Organoleptik Kenampakan Ikan Teri Kering

Grafik diatas Menunjukkan bahwa nilai rata-rata kenampakan ikan teri kering dimana untuk perlakuan lama penyimpanan 1 bulan dengan nilai 8,70 dengan spesifikasi (utuh, bersih, rapi, bercahaya menurut jenis), kemudian pada penyimpanan 2 bulan dengan nilai 7,64 dengan spesifikasi (utuh, bersih, kurang rapi, bercahaya menurut jenis), pada penyimpanan 3 bulan dengan nilai 6,59 dengan spesifikasi (utuh, bersih agak kusam). Jika dibandingkan dengan standar nilai organoleptik yang ditetapkan oleh SNI 01-2708-1992 (BSN, 1992), produk ikan teri kering hasil penelitian ini masih sesuai dengan standar.

Hasil analisis ragam menunjukkan bahwa lama penyimpanan produk memberikan pengaruh sangat nyata pada taraf $(\mathrm{p}>0,05)$. Selanjutnya hasil uji lanjut BNT (beda nyata terkecil), disimpulkan bahwa ketiga perlakuan lama penyimpanan berbeda sangat nyata antara satu dengan yang lain. Kenampakan ikan teri kering terlihat sama untuk semua perlakuan lama penyimpanan dan tidak terdapat kerusakan fisik serta tidak adanya perubahan warna yang berarti, selain itu lama penyimpanann yang semakin lama, membuat penerimaan panelis cenderung semakin menurun.

Semakin lama melakukan penyimpanan maka terjadinya penurunan nilai kenampakan. Hal ini disebabkan karena adanya pengaruh panas selama pengeringan sehingga menyebabkan terjadinya reaksi pencoklatan (maillard) antara asam amino dengan gula pereduksi dan kandungan garam yang 
ada dalam produk. Menurut Lee (1983), bahwa gula pereduksi pada ikan merupakan hasil pemecahan glikogen sesaat setelah ikan mati. Reaksi antara asam amino dan gula pereduksi akan membentuk melanoidin, suatu polimer berwarna coklat yang dapat menurunkan nilai kenampakan produk. Pencoklatan juga terjadi karena reaksi antara protein, peptida dan asam amino dengan hasil dekomposisi lemak. Reaksi Maillard ini mudah terjadi pada bahan pangan yang berkadar garam tinggi dan berkadar air lebih besar dari 20\% (Jay, 1992).

Hal yang sama oleh Indriati et al. (1991) menemukan bahwa reaksi pencoklatan ikan kering di Indonesia kebanyakan terjadi pada produk berkadar garam $7,70 \%-16,90 \%$ dengan nilai aktifitas air (Aw) antara 0,70-0,78. Untuk mempertahankan mutu ikan kering, hal-hal tersebut di atas harus menjadi pertimbangan di dalam melakukan proses pengolahan.

\section{Bau}

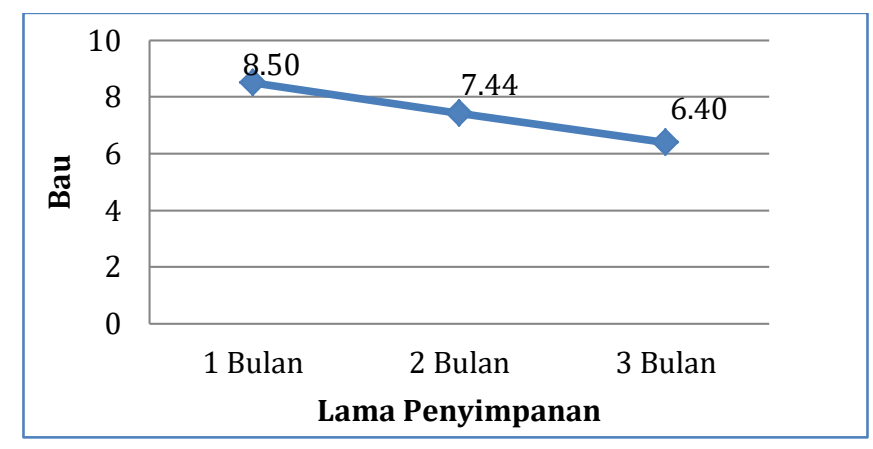

Gambar 2. GrafikNilaiOrganoleptikBaulkan Teri Kering

Grafik diatas Menunjukkan bahwa nilai rata-rata bau ikan teri kering untuk perlakuan lama penyimpanan 1 bulan dengan nilai 8,50 dengan spesifikasi (harum, spesifik jenis,tanpa bau tambahan), kemudian pada penyimpanan 2 bulan dengan nilai 7,44 dengan spesifikasi (hampir netral, sedikit bau tambahan) dan mengalami penurunan pada penyimpanan 3 bulan dengan nilai 6,40 dengan spesifikasi (netral, sedikit bau tambahan).

Hasil analisis ragam menunjukkan bahwa lama penyimpanan ikan teri kering memberikan pengaruh nyata terhadap nilai bau pada taraf $(p>0,05)$. Selanjutnya hasil uji lanjut BNT (beda nyata terkecil), disimpulkan bahwa perlakuan lama penyimpanan 1 bulan berbeda dengan penyimpanan 2 bulan dan 3 bulan.

Terjadi penurunan nilai bau pada penyimpanan 3 bulan, sehingga untuk aplikasi lebih lanjut akan mempengaruhi penerimaan konsumen terhadap produk ikan teri kering yang disimpan lebih dari 4 bulan. Selama masa penyimpanan 3 bulan, penurunan nilai organoleptik bau relatif kecil. Hal ini diduga karena metabolit sederhana yang berasal dari protein dan lemak akan menghasilkan bau amonia, busuk, tengik dan bau lainnya yang tidak diinginkan. Menurut Bligh et al., (1988), pengeringan dapat mendorong terjadinya oksidasi dan ketengikan pada lemak sehingga dapat menurunkan nilai organoleptik bau.

\section{Rasa}

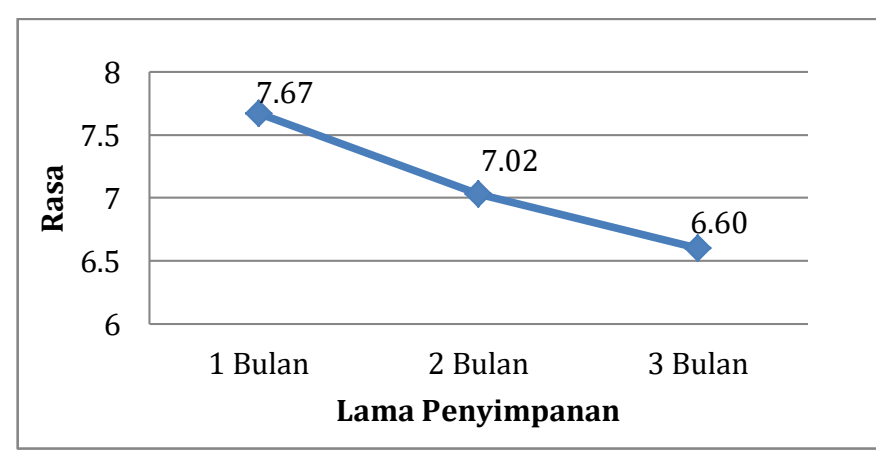

Gambar 3. Grafik Nilai Organoleptik Rasa Ikan Teri Kering

Hasil penilaian panelis terhadap rasa ikan teri kering selama penyimpanan menunjukkan bahwa rata-rata nilai yang diperoleh adalah $7,67-6,60$. Skor 7 pada penilaian organoleptik rasa dengan 
spesifikasi adalah sangat enak, spesifik jenis, tanpa rasa tambahan. Jika dibandingkan dengan standar nilai organoleptik yang ditetapkan oleh SNI 01-2708-1992 (BSN, 1992), produk ikan teri kering hasil penelitian ini masih sesuai dengan standar.

Hasil analisis ragam menunjukkan bahwa lama penyimpanan ikan teri kering selama 1 bulan, 2 bulan dan 3 bulan secara keseluruhan memberikan pengaruh nyata (Lampiran 4a). Selanjutnya hasil uji lanjut BNT (beda nyata terkecil), disimpulkan bahwa ketiga perlakuan lama penyimpanan berbeda sangat nyata antara perlakuan satu dengan yang lain pada taraf $(p>0,05)$ terhadap penurunan nilai rasa ikan teri kering yang dihasilkan.

Selama penyimpanan dari bulan ke-1 sampai bulan ke-3 penurunan nilai rasa tidak terlalu nampak untuk semua perlakuan. Hal ini terjadi karena jumlah bakteri relatif kecil sehingga senyawa makromolekul yang dirombak juga sedikit dan tidak begitu mempengaruhi rasa dari produk ikan teri kering yang dihasilkan. Menurut penelitian Sedjati (2006), bahwa komponen citarasa pada ikan teri kering juga dipengaruhi oleh peristiwa perombakan senyawa makromolekul yang menghasilkan zatzat yang tidak diinginkan dalam bahan pangan.

\section{Konsistensi}

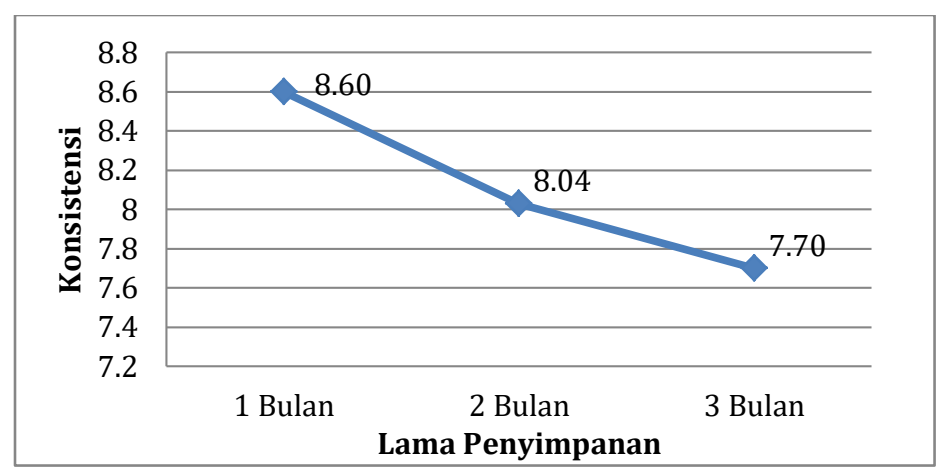

Gambar 4. Grafik Nilai Organoleptik Konsistensi Ikan Teri Kering

Hasil penilaian panelis terhadap konsistensi ikan teri kering selama penyimpanan menunjukkan bahwa rata-rata nilai yang diperoleh adalah 8,60-7,70. Skor 8,60 pada penilaian organoleptik konsistensi dengan spesifikasi adalah padat, kompak, lentur, cukup kering. Jika dibandingkan dengan standar nilai organoleptik yang ditetapkan oleh SNI 01-2708-1992 (BSN, 1992), produk ikan teri kering hasil penelitian ini masih sesuai dengan standar.

Hasil analisis ragam menunjukkan bahwa lama penyimpanan ikan teri kering selama 1 bulan, 2 bulan dan 3 bulan secara keseluruhan memberikan pengaruh nyata terhadap nilai konsistensi. Selanjutnya hasil uji lanjut BNT, disimpulkan bahwa ketiga perlakuan lama penyimpanan berbeda sangat nyata antara perlakuan satu dengan yang lain pada taraf $(p>0,05)$ terhadap nilai konsistensi ikan teri kering yang dihasilkan.

Nilai rata-rata menunjukkan bahwa, penilaian panelis hampir sama dan range nilai yang tidak terlalu jauh untuk setiap perlakuan. Walaupun demikian penilaian panelis cenderung menurun dengan semakin lamanya melakukan penyimpanan. Kadar air yang semakin rendah terjadi karena peningkatan garam yang terkandung dalam bahan baku ikan teri, tingkat pengemasan dan lama pengeringan sehingga produk menjadi padat dan kompak serta berpengaruh pada tingkat penerimaan panelis terhadap nilai konsistensi ikan teri kering yang dihasilkan. Hal ini sesuai menurut Rahman (2007), bahwa otot dan sel ikan akan mengikat akibat keluarnya kandungan air dalam tubuh ikan setelah melakukan pengeringan dan proses dehidrasi osmosis.

\subsection{Karakteristik Mutu Kimiawi Ikan Teri Kering \\ 1. Kadar Air}

Disamping sumber air yang nyata berupa air dan minuman lain, hamper semua makanan mengandung air. Sebagian besar buah dan sayuran mengandung sampai 95\% air, sedangkan pada daging umumnya mengandung 50-60\% (Almitser, 2004). Rata-rata hasil analisis kadar air pada dapat dilihat pada gambar berikut. 


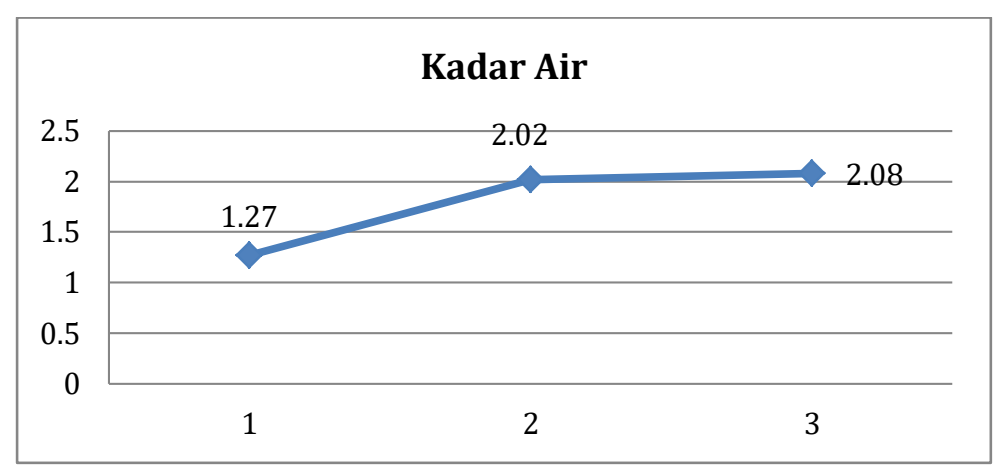

Gambar 5. Grafik Nilai Kadar Air Ikan Teri Kering

Berdasarkan grafik diatas menunjukan bahwa kadar air pada ikan teri kering tertinggi adalah 2,08 pada penyimpanan 3 bulan, sedangkan nilai terendah adalah 1,27 yaitu diperoleh pada penyimpanan 1 bulan.

\section{Kadar Abu}

Kadar abu dikenal sebagai unsure mineral atau zat organic. Abu merupakan salah satu komponen dalam bahan makanan, komponen ini terdiri dari mineral-mineral seperti kalsium, fosfor, natrium, tembaga (winarno, 1995). Rata-rata hasil analisis kimia kadar abu ikan teri kering dapat dilihat pada Gambar brikut.

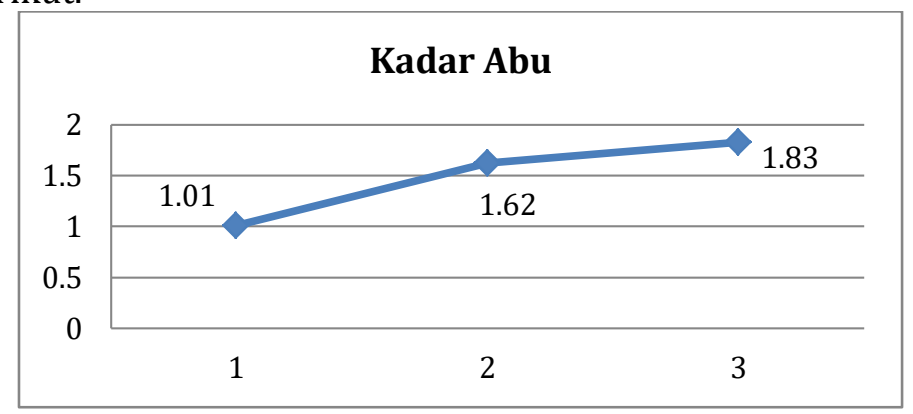

Gambar 6. Grafik Nilai Kadar Abu Ikan Teri Kering

Berdasarkan grafik pada Gambar diatas menunjukan bahwa kadar abu bada ikan teri kering tertinggi adalah 1,83 yaitu diperoleh pada penyimpanan 3 bulan. Sedangkan nilai terendah adalah 1,01 yaitu diperoleh pada penyimpanan bulan. Grafik diatas juga menunjukan bahwa semakin lama penyimpanan ikan teri kering maka kadar abu mengalami kenaikan.

\section{Kadar Protein}

Kadar protein merupakan rantai asam amino yang diperlukan oleh tubuh. Protein memiliki peranan penting dalam pertumbuhan (Gardjito, 2009). Rata-rata hasil analisis kadar protein pada ikan teri kering dapat dilihat pada Gambar berikut.

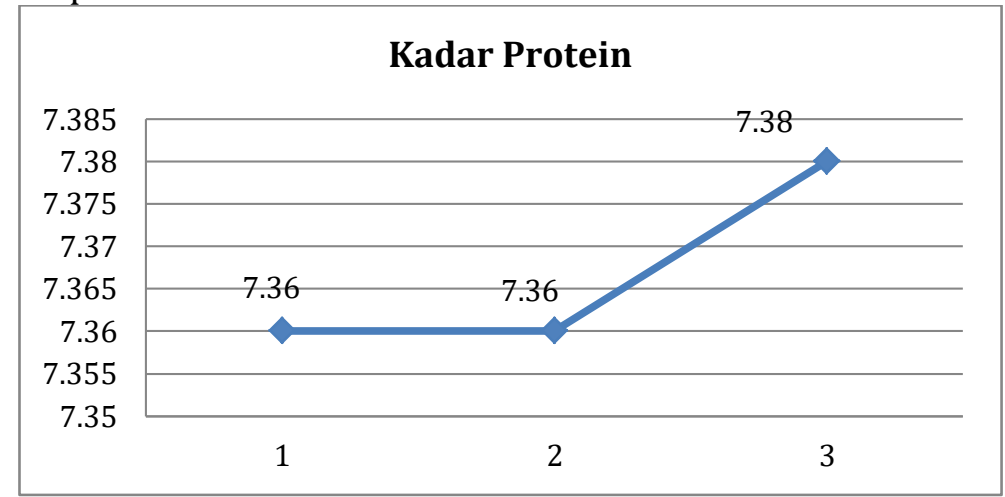

Gambar 7. Grafik Nilai Kadar Protein Ikan Teri Kering 
Grafik diatas menunjukan bahwa kadar protein pada produk ikan teri kering tertinggi adalah 7,38 yaitu diperoleh pada penyimpanan 3 bulan. Sedangkan nilai terendah 7,36 yaitu diperoleh pada penyimpanan 1 bulan dan 2 bulan.

\section{Kadar Lemak}

Kadar lemak merupakan sumber energy yang lebih efektif dibandingkan dengan karbohidrat. Satu gram lemak atau minyak dapat menghasilkan 9 kkal energi. Lemak juga berperan sebagai sumber kalsium dan energi (Gardjito, 2009). Rata-rata hasil analisis kadar lemak pada produk ikan teri kering dapat dilihat pada gambar berikut.

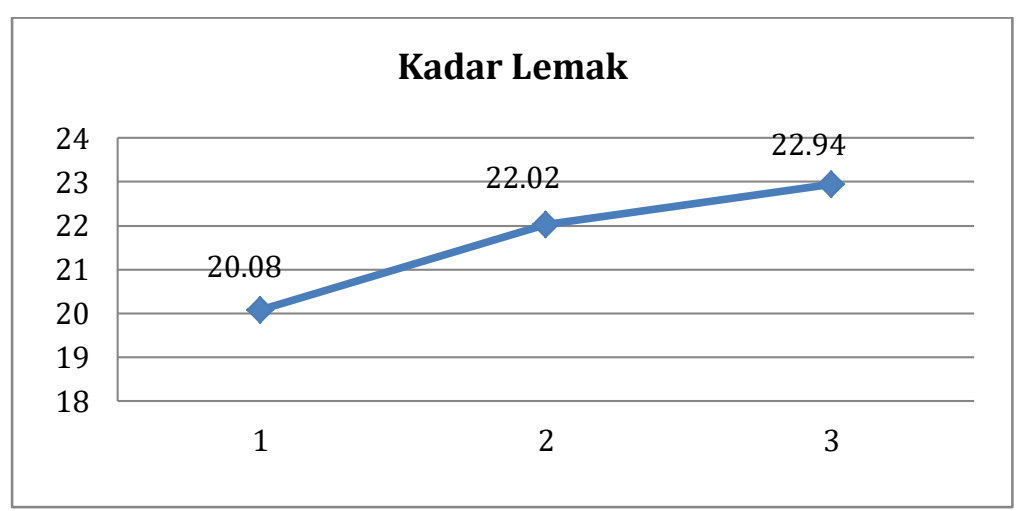

Gambar 8. Grafik Nilai Kadar Lemak Ikan Teri Kering

Grafik diatas menunjukan bahwa kadar lemak pada produk ikan teri kering tertinggi adalah 22,94 yaitu diperoleh pada penyimpanan 3 bulan. Sedangkan nilai terendah adalah 20,08 yaitu diperoleh pada penyimpanan 1 bulan.

\section{Karbohidrat by difference}

Kadar kabrbohidrat ditentukan dengan by difference yaitu hasil pengurangan dari $100 \%$ dengan kadar air, kadar abu, kadar protein dan kadar lemak sehingga kadar karbohidrat tergantung pada factor pengurangannya. Hal ini disebabkan karena karbohidrat sangat berpengaruh pada factor kandungan zat gizi lainnya. Penentuan dengan cara ini kurang akurat dan merupakan perhitungan kasar sebab karbohidrat yang dihitung termasuk serat kaasar yang tidak menghasilkan energi (Winarno, 1997). Rata-rata analisis kadar karbohidrat pada ikan teri kering dapat dilihat pada Gambar berikut.

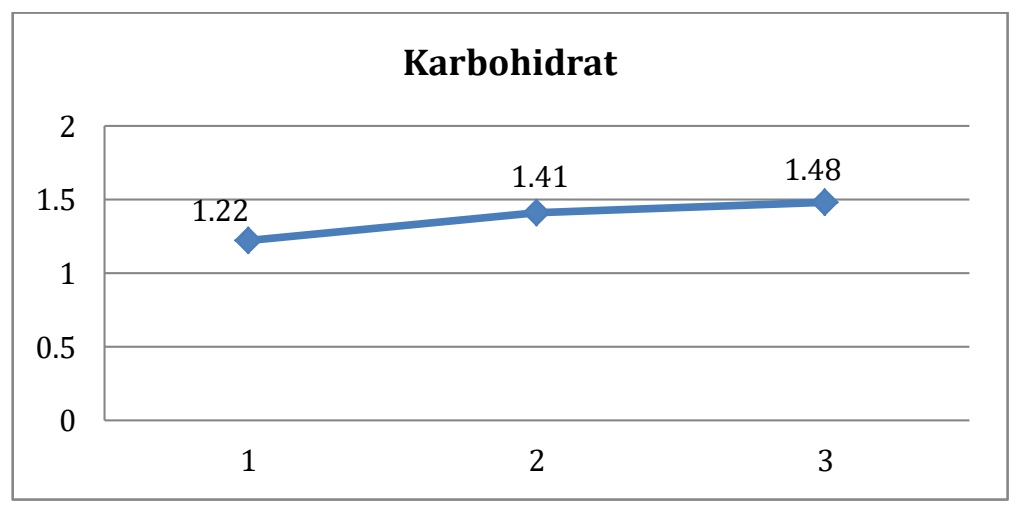

Gambar 9. Grafik Nilai Kadar Karbohidrat Ikan Teri Kering

Gambar diatas menunjukan bahwa kadar karbohidrat pada produk ikan teri kering tertinggi adalah 1,48 yaitu diperoleh pada penyimpanan 3 bulan. Sedangkan nilai terendah adalah 1,22 yaitu diperoleh pada penyimpanan 1 bulan..

\section{PENUTUP}

Dimana rata-rata nilai dari ke empat parameter adalah Kenampakan (8-7), Bau (8-7), Rasa (7), Konsistensi (8-7). Hasil Uji karakteristik kimiawi meliputi kadar air dengan nilai (2,08 pada penyimpanan 3 bulan, sedangkan nilai terendah adalah 1,27), kadar abu (1,83 yaitu diperoleh pada 
penyimpanan 3 bulan. Sedangkan nilai terendah adalah 1,01 yaitu diperoleh pada penyimpanan bulan), kadar protein (7,38 yaitu diperoleh pada penyimpanan 3 bulan. Sedangkan nilai terendah 7,36 yaitu diperoleh pada penyimpanan 1 bulan dan 2 bulan), kadar lemak (22,94 yaitu diperoleh pada penyimpanan 3 bulan. Sedangkan nilai terendah adalah 20,08 yaitu diperoleh pada penyimpanan 1 bulan) dan Karbohidrat (1,48 yaitu diperoleh pada penyimpanan 3 bulan. Sedangkan nilai terendah adalah 1,22 yaitu diperoleh pada penyimpanan 1 bulan).Perlu adanya penilitian lanjutan dengan bahan baku t yang berbeda.

\section{DAFTAR PUSTAKA}

Adawyah, R. 2007. Pengolahan dan Pengawetan Ikan. Penerbit PT Bumi Aksara. Jakarta

Afrianto, E., dan E. Liviawaty., 1989. Pengawetan dan Pengolahan Ikan. Kanisius. Yogyakarta.

Astawan, M. 2001. Penggunaan dan Pengolahan Hasil Perikanan. Penerbit Universitas Terbuka, Departemen Pendidikan Nasional (Depdiknas). Jakarta.

[AOAC] Association of Official Analytical Chemist. 1995. Official methods of analysis. Washington DC.

[DKP] Dinas Kelautan dan Perikanan. 2016. Laporan Statistik Perikanan Tangkap. Ternate : Dinas Kelautan dan Perikanan Kabupaten Halmahera Barat.

Direktorat Jendral Prerikanan. 1981. Pembuatan ikan asin. Balai Besar Penelitian dan Pengembangan Industri Hasil Perikanan. Publikasi No.4.

Irawan, 1997. Pengawetan Ikan dan Hasil Perikanan. Cara Mengelolah dan Mengawetkan Secara Tradisional dan Modern. Penerbit Aneka Ilmu. Solo.

Moeljanto, 1982. Penggaraman dan Pengeringan Ikan. Penerbit PT. Penebar Swadaya. Jakarta.

Moeljanto, 1992. Pengolahan dan Pengawetan Hasil Perikanan. Penebar Swadaya. Jakarta.

Opstvedt, J. 1988. Influence of Drying and Smoking on Protein Quality in J.R. Burt (Ed.) Fish Smoking and Drying : The Effect of Smoking and Drying on TheNutritional Properties of Fish. Elsevier Applied Science, London.

Pelczaer MJ, dan E.C.S. Chan. 2005. Dasar-dasar Mikrobiologi. Penerbit Universitas Indonesia.

Steel RGD dan Torrie JH. 1991. Prinsip dan Prosedur Statestika. Penerjemah: Sumantri B. Jakarta: PT. Gramedia Pustaka Utama.

Tangke U., 2014. Parameter populasi dan tingkat eksploitasi ikan tongkol (Euthynnus affinis) di perairan Pulau Morotai. Agrikan: Jurnal Ilmiah Agribisnis dan Perikanan. 7(1):74-81. DOI: 10.29239/j.agrikan.7.1.74-81.

Tangke U., Deni S., \& Aunaka A., 2018a. The Influence of Using Bait Types to the Number and Composition of Fishing Traps Catch in South Ternate Waters. IOP Conference Series: Earth and Environmental Science. 175(1):12231. DOI: 10.1088/1755-1315/175/1/012231.

Tangke U., Sangadji I., Rochmady R., \& Susiana S., 2018b. A population dynamic aspect of Selaroides leptolepis in the coastal waters of South Ternate Island, Indonesia. AACL Bioflux. 11(4):13341342.

Winarno, FG. Fardiaz S, Fardiaz D. 2008. Indonesian Fermented Food Lecture Presented to Regional Graduate Nutrition Course. Bogor: Southeast Asia Minister of Education Organization (SEAMEO) Bogor Agricultural University. 